Aristotle's Physics VIII, Translated into Arabic by Ishāa ibn Ḥunayn (9th c.) 


\section{Scientia Graeco-Arabica}

herausgegeben von

Marwan Rashed

Band 30

De Gruyter 


\section{Aristotle's Physics VIII, Translated into Arabic by Ishāq ibn Hunayn (9th c.)}

Edited with Introduction and Glossaries by Rüdiger Arnzen

With a Contribution by Pieter Sjoerd Hasper

De Gruyter 
ISBN 978-3-11-057699-3

e-ISBN (PDF) 978-3-11-058208-6

ISSN 1868-7172

Library of Congress Control Number: 2020945249

Bibliographic information published by the Deutsche Nationalbibliothek

The Deutsche Nationalbibliothek lists this publication in the Deutsche Nationalbibliografie; detailed bibliographic data are available on the Internet at http://dnb.dnb.de.

(C) 2021 Walter de Gruyter GmbH, Berlin/Boston

Printing: CPI books GmbH, Leck

www.degruyter.com 